\title{
A Planar Schiff Base Platinum(II) Complex: Crystal Structure, Cytotoxicity and Interaction with DNA
}

\author{
Yan Peng, Hui Zhong, Zhen-Feng Chen,* Yan-Cheng Liu, Guo-Hai Zhang, Qi-Pin Qin, and \\ Hong Liang*
}

State Key Laboratory Cultivation Base for the Chemistry and Molecular Engineering of Medicinal Resources, School of Chemistry \& Chemical Engineering of Guangxi Normal University; Guilin 541004, P. R. China. Received April 3, 2013; accepted December 2, 2013

\begin{abstract}
A new platinum(II) complex of salphen derivative, namely Schiff base ligand that derived from $o$-phenylenediamine and 5-chlorosalicylaldehyde was synthesized. The complex possessed a planar mononuclear structure. The in vitro cytotoxicities of the complex were evaluated by microculture tetrozolium (MTT) assay against seven human tumor cell lines with the $\mathrm{IC}_{50}$ values of $c a .11 .61 \mu \mathrm{M}$. Cell cycle analysis indicated that the complex induced apoptosis and G1-phase arrest in A549 cells. The results of colony formation assay showed that the complex could suppress the proliferation and viability of A549 cells. The binding of the complex to potential target DNA were investigated by fluorescence spectroscopy, viscosity measurements, fluorescence polarization and agarose gel electrophoresis. The results suggest that the most probable binding mode of the complex is intercalation.
\end{abstract}

Key words Schiff base; platinum(II) complex; crystal structure; antitumor activity; DNA binding

The study of platinum(II)-containing anticancer drugs has been a hot topic in medicinal inorganic chemistry over the past few decades since cisplatin was identified as the very efficient anticancer agent. ${ }^{1,2)}$ Thousands of platinum(II/IV) complexes have been synthesized and assayed for their in vitro or in vivo anticancer activities. However, only thirties of them entered clinical trials. Discovering more potent platinumbased anticancer drugs while with less side effects represents a major challenge. A few new strategies such as some trans, monofunction in geometry and classical intercalation to DNA, have been applied for designing new platinum(II) complexes showed different anticancer mechanisms with cisplatin to overcome the intrinsic or acquired resistance, moreover, a great of progress have been made. ${ }^{3-5}$ )

Schiff bases are versatile ligands and have been playing key roles in the development of new bioactive agents, ${ }^{6,7)}$ and in particular, anticancer and antibacterial agents. Metal complexes of Schiff bases have been shown to be able to interact with several primary biogenic macromolecules such as DNA, RNA and peptides. ${ }^{8-10)}$ Particularly, the Schiff base metal complexes derived from salicylaldehyde were effective for cleaving DNA. ${ }^{11-14)}$ In this paper, we attempt to develop new platinum(II) Schiff base anticancer agents that binding non-covalently to DNA. A new planar platinum(II) complex of Schiff base ligand $\left(\mathrm{H}_{2}-\mathrm{LCl}_{2}\right)$ derived from $O$-phenylenediamine and 5-chlorosalicylaldehyde was synthesized. Its in vitro antitumor activities and its influence on cell cycle, cell apoptosis and colony formation, as well as its binding properties to potential target DNA were evaluated.

\section{Experimental}

Materials All the chemical reagents and solvents were of analytical grade. $\mathrm{PtCl}_{2}$, 1,2-diaminobenzene, 5-chlorosalicylaldehyde were purchased from Alfa-aesar. GelRed was purchased from Biotium. Agarose, ethidium bromide (EB), calf thymus DNA (ct-DNA) and pUC19 plasmid DNA were pur-

The authors declare no conflict of interest. chased from Sigma-Aldrich. They were all used as received without further purification unless noted specifically.

Instrumentation and Methods The $\mathrm{pH}$ value of buffer solution was measured on a Sartorius Professional PP-20 pH Meter. Elemental analyses $(\mathrm{C}, \mathrm{H}$ and $\mathrm{N}$ ) were carried out on a PerkinElmer, Inc. Series II CHNS/O 2400 elemental analyzer. ${ }^{1} \mathrm{H}-\mathrm{NMR}$ and ${ }^{13} \mathrm{C}-\mathrm{NMR}$ spectra were recorded on a Bruker AV-500 NMR spectrometer with DMSO- $d_{6}$ as solvent. Electrospray ionization (ESI)-MS spectra were performed on Thermofisher Scientific Exactive LC-MS Spectrometer. Fluorescence emission spectra were performed on a Shimadzu RF-5301/PC spectrofluorometer. DNA viscosity was measured on a Brookfield DV-II pro digital viscometer equipped with Ultra Low Adaptor immersed in a TC-502D thermostatic bath.

Synthesis. Synthesis of Ligand A mixture of $o$-phenylenediamine $(1.08 \mathrm{~g}, 0.01 \mathrm{~mol}), 5$-chlorosalicylaldehyde $(3.12 \mathrm{~g}$, $0.02 \mathrm{~mol})$ dissolved in distilled water $(20 \mathrm{~mL})$ was refluxed with stirring. The solution was continuously refluxed in water-bath at $80^{\circ} \mathrm{C}$ for $6 \mathrm{~h}$. After cooling the reaction mixture to the room temperature, the yellow precipitate formed and filtrated. Then the yellow precipitate was re-crystallized from methanol, and dried, with a yield of $71 \%$. ${ }^{1} \mathrm{H}-\mathrm{NMR}(500 \mathrm{MHz}$, DMSO- $\left.d_{6}\right) \delta 12.93$ (s, 2H, Ar-OH), $8.93(\mathrm{~s}, 2 \mathrm{H}, \mathrm{CH}=\mathrm{N}), 7.78$ (d, $J=2.6 \mathrm{~Hz}, 2 \mathrm{H}, \mathrm{H}-\mathrm{Ar}$ ), 7.45-7.38 (m, 4H, H-Ar), 7.12-6.96 (m, 4H, H-Ar). ${ }^{13} \mathrm{C}-\mathrm{NMR}\left(125 \mathrm{MHz}, \mathrm{DMSO}-d_{6}\right) \delta 162.77$, $159.52,142.52,136.21,133.40,131.27,128.64,127.81,122.99$, 121.28, 120.11, 119.97, 119.53, 119.43, 119.22. Elemental Anal. Calcd for $\mathrm{C}_{20} \mathrm{H}_{14} \mathrm{Cl}_{2} \mathrm{~N}_{2} \mathrm{O}_{2}$ : C: $62.35 \%, \mathrm{H}: 3.66 \%$, N: $7.27 \%$, Found C: $62.31 \%$, H: $3.69 \%$, N: $7.30 \%$.

Synthesis of Complex The mixture of $\mathrm{Pt}(\mathrm{DMSO})_{2} \mathrm{Cl}_{2}$ (0.041 g, $0.1 \mathrm{mmol}), \mathrm{H}_{2}-\mathrm{ClL}_{2}(0.046 \mathrm{~g}, 0.12 \mathrm{mmol})$, ethanol $(1 \mathrm{~mL})$, dimethyl sulfoxide (DMSO) $(1 \mathrm{~mL})$ were heated to $80^{\circ} \mathrm{C}$ and was stirred for $12 \mathrm{~h}$. After cooling to the room temperature, the reddish-brown crystals were obtained. Yield: $0.049 \mathrm{~g}, 56 \%$. Single crystals suitable for X-ray diffraction analysis were harvested by slow evaporation of the re-crystallized ethanol solution. ${ }^{1} \mathrm{H}-\mathrm{NMR}\left(500 \mathrm{MHz}, \mathrm{DMSO}-d_{6}\right) \delta 9.57$ $(\mathrm{s}, 1 \mathrm{H}, \mathrm{CH}=\mathrm{N}), 8.32$ (s, 2H, $\mathrm{CH}=\mathrm{N}, \mathrm{Ar}), 8.23(\mathrm{~d}, J=7.7 \mathrm{~Hz}$, 
1H, H-Ar), 7.90 (s, 1H, H-Ar), 7.54 (d, $J=11.0 \mathrm{~Hz}, 2 \mathrm{H}, \mathrm{H}-\mathrm{Ar}$ ), 7.37 (dd, $J=25.1,17.2 \mathrm{~Hz}, 4 \mathrm{H}, \mathrm{H}-\mathrm{Ar}), 6.95$ (d, $J=9.0 \mathrm{~Hz}, 1 \mathrm{H}$, H-Ar). ${ }^{13} \mathrm{C}-\mathrm{NMR} \quad\left(125 \mathrm{MHz}, \mathrm{DMSO}-d_{6}\right): \delta 161.78,148.68$, $147.35,140.82,134.36,133.04,128.79,128.27,126.82,123.90$, 116.96. ESI-MS: $m / z 578[\mathrm{M}+\mathrm{H}]^{+}$. Elemental Anal. Calcd for $\mathrm{C}_{20} \mathrm{H}_{12} \mathrm{Cl}_{2} \mathrm{~N}_{2} \mathrm{O}_{2} \mathrm{Pt}: \mathrm{C}: 41.54 \%, \mathrm{H}: 2.09 \%$, N: 4.84\%, Found C: $41.58 \%$, H: $2.11 \%$, N: 4.89\%.

X-Ray Crystallography The data collection of single crystal of the complex was carried out on an Agilent SuperNova CCD diffractometer equipped with graphite monochromated $\mathrm{MoK} \alpha$ radiation $(\lambda=0.71073 \AA)$ at room temperature. The structures were solved with direct methods and refined using SHELX-97 programs. ${ }^{15,16)}$ The non-hydrogen atoms were located in successive difference Fourier synthesis. The final refinement was performed by full-matrix least-squares methods with anisotropic thermal parameters for no-hydrogen atoms on $F^{2}$. The hydrogen atoms were added theoretically and riding on the concerned atoms. The paramerters used intensity collection and refinements are summarized in Table 1 together with the crystal data.

Cytotoxicity Assay in Vitro The tumor cell lines A549, MDA-MB-231, HepG2, T24, MG-63, MGC-803, HUVEC and the normal lung fibroblast cell lines were obtained from the Shanghai Cell Bank, Chinese Academy of Science. All cells were grown in RPMI-1640 medium supplemented with $10 \%$ $(\mathrm{v} / \mathrm{v})$ fetal bovine serum, $2 \mathrm{~mm}$ glutamine, $100 \mathrm{U} / \mathrm{cm}^{3}$ penicillin, and $100 \mathrm{U} / \mathrm{cm}^{3}$ streptomycinin, in a highly humidified atmosphere of $95 \%$ air with $5 \% \mathrm{CO}_{2}$ at $310 \mathrm{~K}$. The cytotoxicities of the complex and the ligand against all cell lines were examined by the MTT assay. ${ }^{17)}$ Three replicate tests were conducted. The growth inhibitory rate of treated cells was calculated using the formula: $\left(\mathrm{OD}_{\text {control }}-\mathrm{OD}_{\text {test }}\right) / \mathrm{OD}_{\text {control }} \times 100 \%$. The experiments were carried out following the procedure reported in the literature. These compounds were incubated with the cell lines for $24 \mathrm{~h}, 48 \mathrm{~h}$ and $72 \mathrm{~h}$, respectively, at the concentrations of $1.25 \mu \mathrm{g} / \mathrm{mL}, 2.5 \mu \mathrm{g} / \mathrm{mL}, 5 \mu \mathrm{g} / \mathrm{mL}, 10 \mu \mathrm{g} / \mathrm{mL}$, $20 \mu \mathrm{g} / \mathrm{mL}$.

Cell Cycle Analysis A549 cells were seeded into a 6-well plate $\left(3 \times 10^{5}\right.$ cells/well $)$ and grown in RPMI 1640 medium supplemented with $10 \%$ fetal bovine serum (FBS) at $37^{\circ} \mathrm{C}$ in a

Table 1. Crystal Data and Structure Refinement for $\left[\mathrm{PtL}_{2}\right]$

\begin{tabular}{ll}
\hline \hline Empirical formula & $\mathrm{C}_{20} \mathrm{H}_{12} \mathrm{Cl}_{2} \mathrm{~N}_{2} \mathrm{O}_{2} \mathrm{Pt}$ \\
\hline Formula weight $(\mathrm{M})$ & 578.31 \\
Crystal system & Monoclinic \\
Space group & $P 2_{1} / n$ \\
$a(\AA)$ & $12.0481(8) \AA$ \\
$b(\AA)$ & $7.9838(4) \AA$ \\
$c(\AA)$ & $18.6451(9) \AA$ \\
$\alpha\left(^{\circ}\right)$ & $90.00^{\circ}$ \\
$\beta\left(^{\circ}\right)$ & $106.248(6)^{\circ}$ \\
$\gamma\left({ }^{\circ}\right)$ & $90.00^{\circ}$ \\
$V /\left(\AA^{3}\right)$ & $1721.82(16) \AA^{3}$ \\
$Z$ & 4 \\
$F(000)$ & 1096 \\
$\theta$ range for data collection $\left(^{\circ}\right)$ & $5.58-52.74^{\circ}$ \\
Reflections collected $/$ unique & $17112 / 3495[R($ int $)=0.0391]$ \\
Goodness-of-fit on $F^{2}$ & 1.067 \\
Final $R$ indices $[I>2 \sigma(I)]$ & $R_{1}=0.0240 \omega R_{2}=0.0535$ \\
$R$ indices (all data) & $R_{1}=0.0297 \omega R_{2}=0.0562$ \\
\hline
\end{tabular}

heavily moisturized environment supplied with $5 \% \mathrm{CO}_{2}$. The next day, the cells were treated with various concentrations of the complex or $0.1 \%$ DMSO for $24 \mathrm{~h}$. Floating and adherent cells were collected and fixed in cold $70 \%$ ethanol at $4{ }^{\circ} \mathrm{C}$ overnight. After washing, the cells were subsequently stained with $50 \mu \mathrm{g} / \mathrm{mL}$ propidium iodide (PI) and $100 \mu \mathrm{g} / \mathrm{mL}$ RNase A for $1 \mathrm{~h}$ in the dark and subjected to flow cytometric analysis in order to determine the percentage of cells at specific phases of the cell cycle. Flow cytometric analysis was performed using a FACSCalibur flow cytometer (Becton-Dickinson, San Jose, CA, U.S.A.) equipped with a $488 \mathrm{~nm}$ argon laser. A high number of events were evaluated for each sample and the cell cycle distribution was analyzed using Cell Quest software (Becton-Dickinson). The results were presented as the number of cells versus the amount of DNA as indicated by the intensity of the fluorescence signal. All experiments were conducted three times.

Apoptosis Assay Cell-apoptosis analysis was conducted using Annexin V-fluorescein isothiocyanate (FITC)/PI apoptosis detection kit (Becton-Dickinson). Cells at the logarithmic phase of growth were harvested using cold phosphate buffered saline (PBS) and collected by centrifugation for $6 \mathrm{~min}$ at $1.000 \times \mathbf{g}$. Cells were resuspended at a density of $1 \times 10^{6}$ cells/ $\mathrm{mL}$ in $1 \times$ binding buffer, stained with FITC-labeled annexin $\mathrm{V}$ and PI for $20 \mathrm{~min}$ and immediately analyzed in a FACScan Flow Cytometer (Becton-Dickinson).

Colony Formation Assay The colony formation assay is a method for analyzing cell proliferation and survival. A549 cells were seeded into a 6 -well plate. After the cells were grown to $70-80 \%$ confluence, the cells were treaded with the complex at the concentrations of $10,20,30 \mu \mathrm{mol} / \mathrm{L}$, respectively. After $24 \mathrm{~h}$, the cells were trypsinized, about 500 cells treaded with the complex were seeded into a new 6-well plate, and allowed to grow for 8-14d. Cells were then washed several times with PBS and fixed for $10 \mathrm{~min}$ in $4 \%$ paraformaldehyde and stained with $0.1 \%$ crystal violet for $5 \mathrm{~min}{ }^{18)}$ The wells were washed with PBS several times, and the colonies formed were counted subsequently. The inhibitory effect of the complex on the colony formation of A549 cells was calculated as the percentage of visible colony numbers in the drugtreated groups compared with that in the untreated control groups. ${ }^{19)}$

Spectroscopic Studies on DNA Interaction The DNA binding studies were performed by first preparing a stock solution of concentration of $2.0 \times 10^{-3} \mathrm{~mol} \cdot \mathrm{L}^{-1}$ by dissolving the complex into DMSO. Tris-buffer solution $\left(5 \times 10^{-3} \mathrm{~mol} \cdot \mathrm{L}^{-1}\right.$ Tris, $50 \times 10^{-3} \mathrm{~mol} \cdot \mathrm{L}^{-1} \mathrm{NaCl}$, adjusted to $\mathrm{pH}=7.3$ by hydrochloric acid) was prepared using double distilled water. A Tris-buffer solution of ct-DNA gave a ratio of UV absorbance at $260 \mathrm{~nm}$ and $280 \mathrm{~nm}$ of $1.85: 1$, indicating that the DNA was sufficiently free from protein. ${ }^{20)}$ The concentration of ct-DNA stock solution was determined spectrophotometrically as $2 \times 10^{-3} \mathrm{M}$ per nucleotide by employing a molar absorption coefficient $\left(6600 \mathrm{M}^{-1} \cdot \mathrm{cm}^{-1}\right)$ at $260 \mathrm{~nm}$. The ct-DNA solution was then stored at $4^{\circ} \mathrm{C}$ within one week before use. In a typical DNA competitive binding experiment, a solution of $1.0 \times 10^{-4} \mathrm{M}$ DNA and $1.0 \times 10^{-5} \mathrm{M} \mathrm{EB}$ with a $[\mathrm{DNA}] /[\mathrm{EB}]$ ratio of $10: 1$ was prepared. Small aliquots of $2.0 \times 10^{-3} \mathrm{~mol} \cdot \mathrm{L}^{-1}$ of the complex were gradually added into the EB-DNA solution to increase the $[$ complex]/[DNA]/[EB] ratios from $1: 10: 1$ to $10: 10: 1$. Fluorescence emission spectra were recorded. The excitation 
and emission slit widths were both $10 \mathrm{~nm}$. The quenching constant $K_{\mathrm{q}}$ of the complex was obtained from restricted linear fitting of $I_{0} / I$ versus [quencher] plot based on the classic SternVolmer equation: $I_{0} / I=1+K_{\mathrm{q}} \times[$ quencher $]{ }^{21)}$ where $I_{0}$ and $I$ are the peak emission intensities of EB-DNA system in the absence and presence of the complex (the quencher), respectively. In the fluorescence polarization experiment, the working solution was pre-incubated for $40 \mathrm{~min}$ before use. The degree of polarization was determined by measuring fluorescence intensities parallel and perpendicular with respect to the plane of linearly polarized excitation light at $595 \mathrm{~nm}$ under $350 \mathrm{~nm}$ UV light excitation. The slit widths were set as $5 \mathrm{~nm}$ and $5 \mathrm{~nm}$ for $E_{\mathrm{x}}$ and $E_{\mathrm{m}}$, respectively. $1.0 \times 10^{-5} \mathrm{~mol} \cdot \mathrm{L}^{-1} \mathrm{GelRed}$ and $7.0 \times 10^{-5} \mathrm{~mol} \cdot \mathrm{L}^{-1} \mathrm{ct}$-DNA were prepared in a $2.0 \mathrm{~mL}$ Tris$\mathrm{NaCl}$ buffer solution. Small aliquots of $2.0 \times 10^{-3} \mathrm{~mol} \cdot \mathrm{L}^{-1}$ of the complex were added into the GelRed/ct-DNA solution to increase [complex]/[DNA] ratios. The fluorescence polarization was measured at about $15 \mathrm{~min}$ after each addition of the complex. All spectroscopic analyses were performed at room temperature. In a typical DNA viscosity measurement, ctDNA was dissolved in BPE buffer $\left(6 \times 10^{-3} \mathrm{~mol} \cdot \mathrm{L}^{-1} \mathrm{Na}_{2} \mathrm{HPO}_{4}\right.$, $2 \times 10^{-3} \mathrm{~mol} \cdot \mathrm{L}^{-1} \quad \mathrm{NaH}_{2} \mathrm{PO}_{4}, \quad 1 \times 10^{-3} \mathrm{~mol} \cdot \mathrm{L}^{-1} \quad \mathrm{Na}_{2}$ EDTA, $\mathrm{pH}=$ 7.2) to prepare a $22 \mathrm{~mL}$ working solution of $1.0 \times 10^{-3} \mathrm{M}$. The complex was then added with increasing [complex]/[DNA] ratios ranging from 0.01 to 0.09 in every 0.01 interval. Circulating bath temperature was maintained at $35.0 \pm 0.5^{\circ} \mathrm{C}$. Viscosity values, $\eta$ (unit: $\mathrm{cP}$ ) were obtained directly by running $0 \#$ spindle in working samples at a rate of $30 \mathrm{rpm}$. Data were presented as $\eta / \eta_{0}$ versus [complex]/[DNA] ratio, in which $\eta_{0}$ and $\eta$ are the viscosities of the DNA solutions in the absence and presence of the complex, respectively. The influence of solvent DMSO upon the measured viscosity values was corrected by using a DMSO viscosity value of $2.03 \mathrm{cP}$ measured at $35.0^{\circ} \mathrm{C}$. All DNA binding experiments were conducted at least in duplicate. ${ }^{22)}$

Agarose Gel Electrophoretic Assay In plasmid DNA unwinding experiments, DMSO stock solution of the complex was diluted to the concentrations of $20,40,60,80$ and $100 \mu \mathrm{M}$ with TBE buffer (TBE: Tris-Boric acid-EDTA buffer solution). The complex of various concentrations and $0.5 \mu \mathrm{g}$ DNA were mixed and brought the volume up to $25 \mu \mathrm{L}$ using TBE buffer so that electrophoresis of each sample can be repeated twice. All samples were incubated at $25^{\circ} \mathrm{C}$ in dark for $4 \mathrm{~h}$, and every $12 \mu \mathrm{L}$ of each sample mixed with $2 \mu \mathrm{L}$ DNA loading buffer was electrophoresed through a $1 \%$ agarose gel (pre-mixed with GelRed) immersed in TBE buffer for $60 \mathrm{~min}$ under a $5 \mathrm{~V} / \mathrm{cm}$ electronic field. Then the gel was visualized and photographed using a BIO-RAD imaging system under a UV-Vis transilluminator. ${ }^{23-25)}$

Statistics The data processing included the Student's $t$ test with $p \leq 0.05$ taken as significance level, using SPSS 13.0.

\section{Results and Discussion}

Synthesis and Characterization The tetradentate Schiff base ligand $\left(\mathrm{H}_{2}-\mathrm{L}\right)$ was synthesized via the condensation reaction of $o$-phenylenediamine and 5-chlorosalicylaldehyde (Chart 1), and characterized by elemental analysis, ${ }^{1} \mathrm{H}-\mathrm{NMR}$, ${ }^{13} \mathrm{C}$-NMR spectroscopy.

The corresponding platinum(II) complex was prepared by the reaction of cis- $\mathrm{Pt}(\mathrm{DMSO})_{2} \mathrm{Cl}_{2}$ with $\mathrm{H}_{2}-\mathrm{L}$ in the presence of ethanol and DMSO under solvothermal conditions (Chart 1), and was characterized by elemental analysis, ${ }^{1} \mathrm{H}-\mathrm{NMR}$, ${ }^{13} \mathrm{C}-\mathrm{NMR}$, and ESI-MS spectroscopy as well as single crystal $\mathrm{X}$-ray diffraction.

Crystal Structure Description The crystallographic data and structure refinement details for the complex were summarized in Table 1. The selected bond lengths $(\AA)$ and bond angles $\left(^{\circ}\right)$ for the complex were given in the caption of Fig. 1. As shown in Fig. 1, the platinum(II) is four-fold coordinated by the Schiff base ligands $\left(\mathrm{H}_{2}-\mathrm{ClL}_{2}\right)$ via the imine nitrogen atoms and the oxygen atom of the hydroxyl groups. The platinum atom resides in a square-planar coordination environment. The bond angles at the platinum atom (N1-Pt1-N2, $\mathrm{N} 1-\mathrm{Pt1}-\mathrm{O} 1, \mathrm{~N} 2-\mathrm{Pt1}-\mathrm{O} 2$ and $\mathrm{O} 1-\mathrm{Pt1}-\mathrm{O} 2)$ were in the range of $85.0-95.0^{\circ}$. The average $\mathrm{Pt}-\mathrm{N}$ and $\mathrm{Pt}-\mathrm{O}$ distances were 1.964 and $2.000 \AA$, respectively, resembling those reported for platinum(II) complexes bearing the $\mathrm{N}_{2} \mathrm{O}_{2}$ ligand donor set. $^{26-28)}$

In Vitro Antitumor Activity Assay The in vitro cytotoxicity of $\mathrm{H}_{2}-\mathrm{L}$ and its complex were evaluated by MTT assay against seven typical human tumor cell lines covering lung, breast, liver, bladder, saos and gastric cancers and normal lung fibroblast cells. The inhibitory effects of $\mathrm{H}_{2}$ - $\mathrm{L}$ and complex on the growth of selected tumor cells were determined after tumor cells being incubated with $20 \mu \mathrm{M}$ of complex and

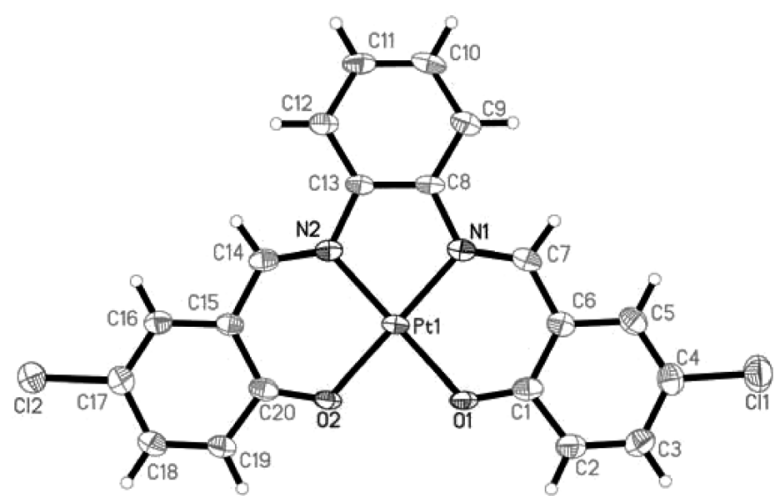

Fig. 1. ORTEP View of Complex $\left[\mathrm{PtL}_{2}\right]$ Showing Atom Labeling, Thermal Ellipsoids Are Drawn at the 30\% Probability

Selected bond lengths $(\AA)$ and bond angles [ $\left.{ }^{\circ}\right]$ : Pt1-N1 1.963(3), Pt2-N2 1.965(3), Pt1-O1 2.002(3), Pt1-O2 1.997(3); N1-Pt1-N2 83.75(15), N1-Pt1-O1 96.03(13), N2-Pt1-O2 95.61(13), O1-Pt1-O2 84.63(12), N1-Pt1-O2 179.06 (13), N2-Pt1-O1 $179.31(12)$

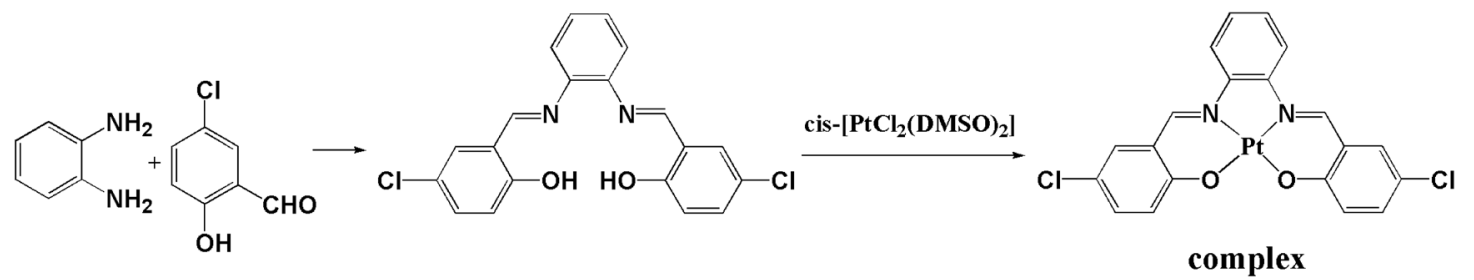


Table 2. Inhibition Rates (\%) of the Ligand and Complex against Six Human Tumour Cells at $20 \mu \mathrm{M}$

\begin{tabular}{lccccc}
\hline \hline & A549 & MDA-MB-231 & HepG2 & T24 & MG63 \\
\hline Ligand & $26.7 \pm 3.6$ & $30.5 \pm 2.3$ & $29.4 \pm 3$ & $22.6 \pm 4.5$ & $28.8 \pm 3.92$ \\
Complex & $71.6 \pm 2.8$ & $89.8 \pm 4.0$ & $82.5 \pm 5.12$ & $68.8 \pm 1.88$ & $79.6 \pm 3.64$ \\
\hline
\end{tabular}

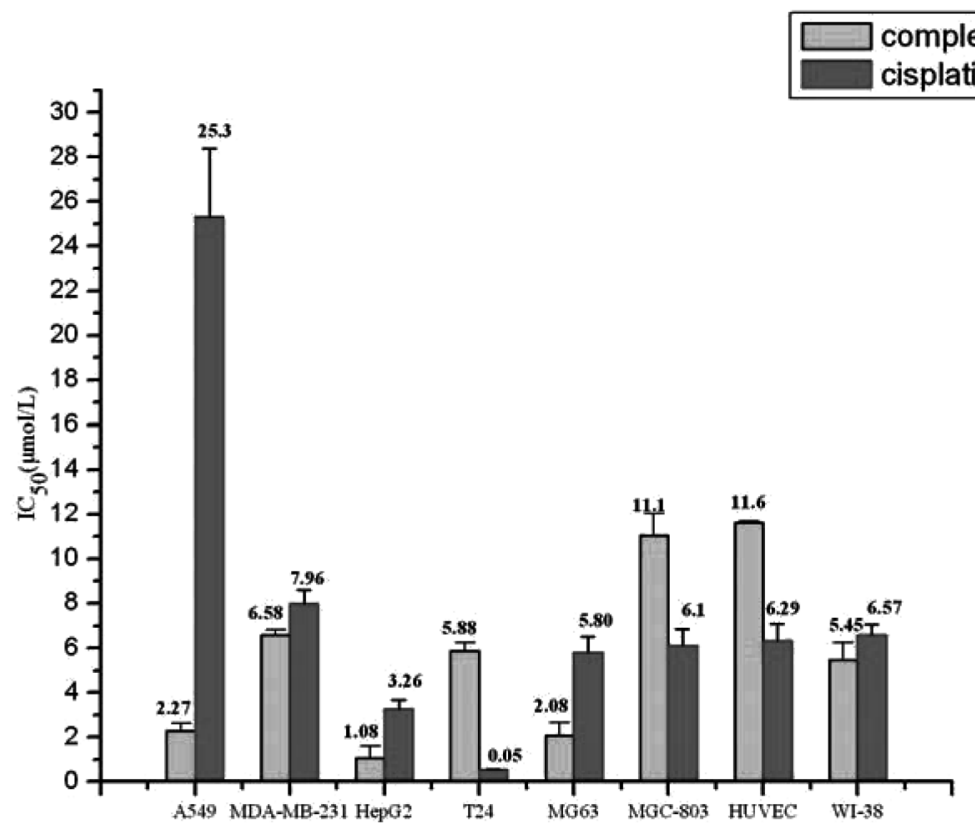

Fig. 2. The $\mathrm{IC}_{50}$ of the Complex against Seven Human Tumor Cell Lines Comparing with Cisplatin

$\mathrm{H}_{2}$-L for $72 \mathrm{~h}$ (Table 2). As shown in Table 2, the complex exhibited enhanced cytotoxicity to all selected tumor cells compared to free ligand. The inhibition of selected tumor cells by complex were all more than $50 \%$, particularly, the inhibition of MDA-MB-231 and HepG2 were as high as $89.8 \%$ and $82.5 \%$, respectively. The in vitro antitumor activities of complex were further quantified by determining the corresponding $\mathrm{IC}_{50}$ values. As shown in Fig. 2, the complex exhibited considerable antitumor activities with $\mathrm{IC}_{50}$ values of $c a .11 .61 \mu \mathrm{M}$. Moreover, the complex had lower $\mathrm{IC}_{50}$ values against $\mathrm{A} 549$, MDA-MB-231, HepG2 and MG-63 compared to cisplatin. The inhibitory activity of complex against HepG2 cells was the strongest, with an $\mathrm{IC}_{50}$ value of $1.06 \mu \mathrm{M}$. Meanwhile, the $\mathrm{IC}_{50}$ of complex against A549 also reached $2.269 \mu \mathrm{M}$, approximately 12 times lower than that of cisplatin. Although the $\mathrm{IC}_{50}$ values of complex against T-24, MGC-803 and HUVEC, i.e., 5.88, 11.05 and $11.61 \mu \mathrm{M}$, respectively, were higher than that of cisplatin, the complex exhibited overall broad-spectrum antitumor activities. It should be noted that the platinum(II) complex displayed considerable cytotoxicity against the normal lung fibroblast cell WI-38, thereby, the platinum(II) complex exhibited little selectivity between cancer cells and normal cells.

Cell Cycle Arrest in A549 Cells To elucidate the mechanisms of inhibition of cell proliferation by complex, the cell cycle arrest in A549 was investigated using fluorescenceactivated cell sorting (FACS). The results are shown in Fig. 3. Treatment of cells with the platinum complex for $48 \mathrm{~h}$ enhanced cell-cycle arrest at the G1 phase, resulting in population increase in the G1 phase $(62.07,70.97,72.24 \%)$ compared with the control cells $(43.27 \%)$ at different concentrations, and the populations of the S and G2 phase decreased only to a certain extent compared with the control cells. We speculated that the decrease of populations in S and G2 phases was the direct result of the population increase in G1 phase. Simultaneously, 3-dose-response studies indicated that the complex exhibited a more profound dose-effect relationship, as shown by the G1-phase arrest at doses of 5, 10, $20 \mu \mathrm{M}$ (Fig. 3). However, cisplatin resulted in population increase in the $\mathrm{S}$ phase. ${ }^{29)}$ Therefore, the mechanism of the suppression of tumor cells' growth by the title platinum(II) complexes might be different from that of cisplatin.

The Complex Induced Apoptosis in A549 Cells The inhibitory effect of the complex on cell proliferation has been further investigated by complex induced cell apoptosis in A549. A549 cells exposed to different doses of complex were examined by FACS with PI and FITC-Annexin V staining. As shown in Fig. 4, the complex triggered apoptosis in A549 cells in a dose-dependent manner at $24 \mathrm{~h}$. Compared to the control groups, the omplex induced $3.5 \%, 6.5 \%$ and $11.7 \%$ of apoptotic cells in A549 cells at concentrations of 5, 10 and $20 \mu \mathrm{M}$ at $24 \mathrm{~h}$, respectively (Fig. 4).

Colony Formation Assay The influence of presence of the complex on the proliferation and survival of A549 cells was shown in Fig. 5. The cells without treated by complex exhibited the greater proliferation ability and survival efficiency in a 6 -well plate. The visual examination indicated that there were more and larger colonies formed in the control groups compared to those formed in the treated groups. In addition, as the complex concentration increased from 10 to $30 \mu \mathrm{mol} / \mathrm{L}$, the number of the colonies formed decreased obviously. These results further supported that the complex could effectively 

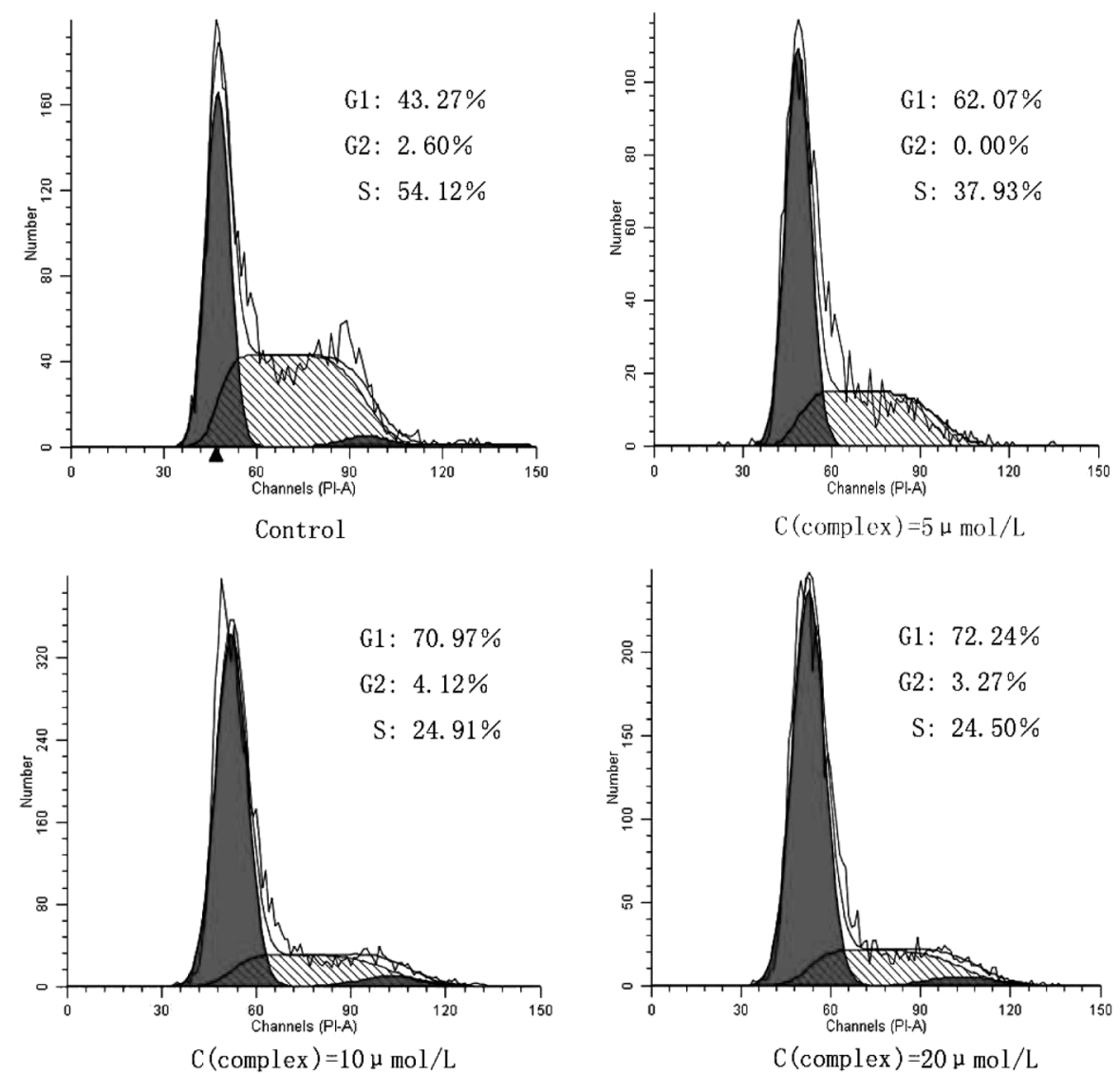

Fig. 3. The Effect of Complex on Cell Cycle Arrest in A549 Cells in Three Doses
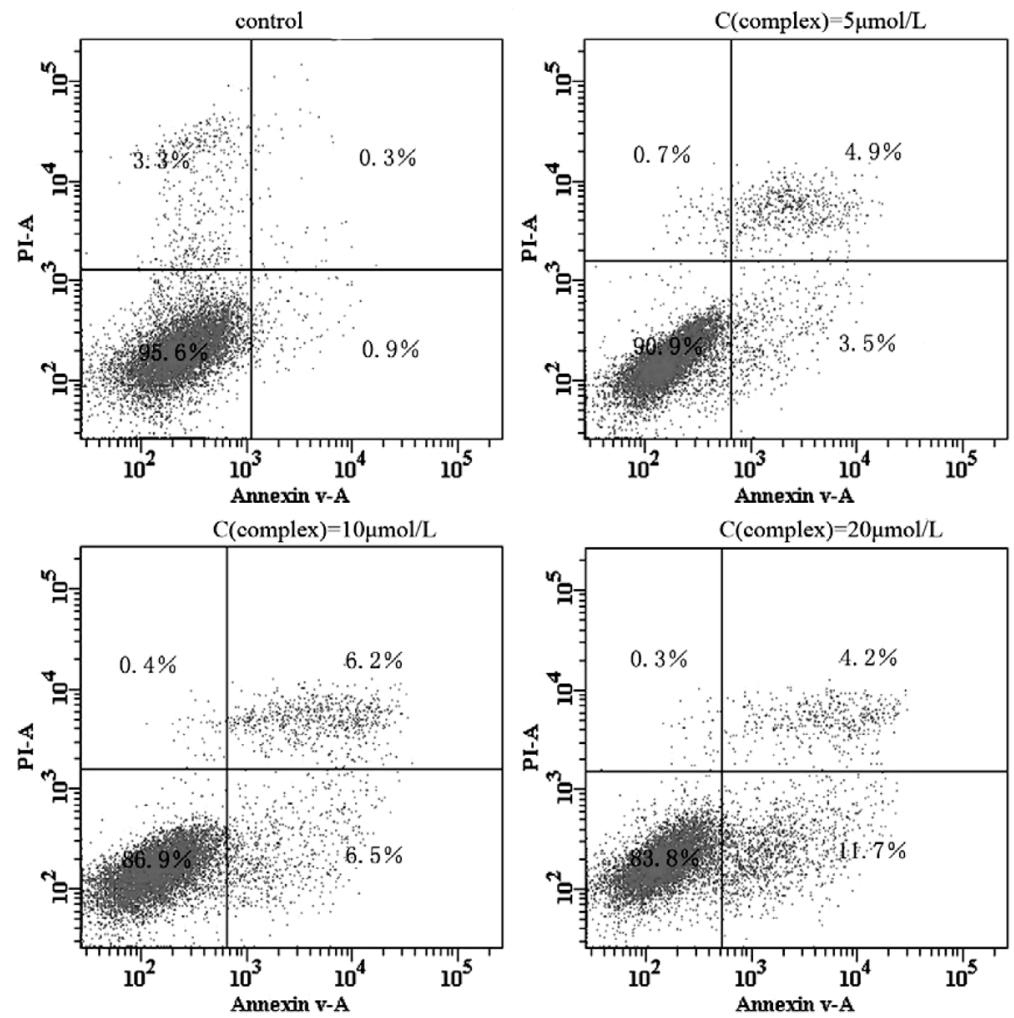

Fig. 4. The Effects of Complex on Apoptosis in A549 Cells in Three Doses 


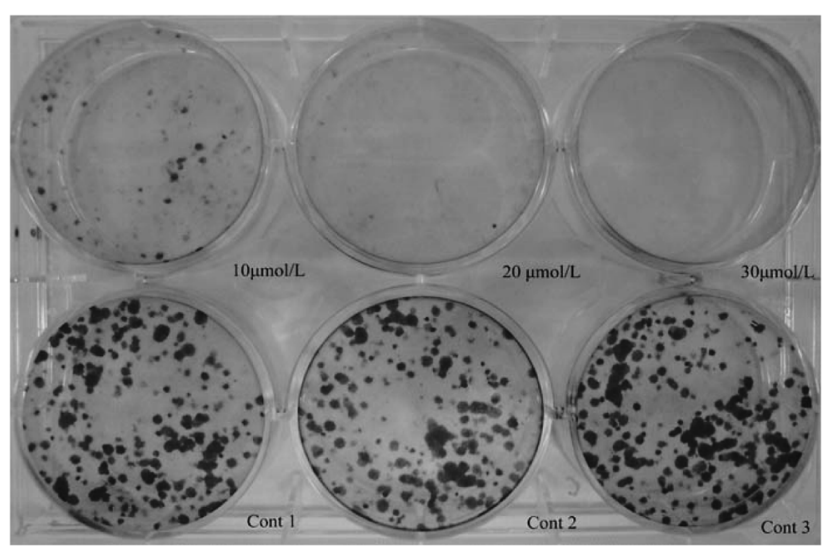

Fig. 5. Colony Formation Assay Was Performed Using Highly Invasive A549 Cells Treated Continuously with Complex at $10 \mu \mathrm{mol} / \mathrm{L}, 20 \mu \mathrm{mol} / \mathrm{L}$, $30 \mu \mathrm{mol} / \mathrm{L}$ for $7 \mathrm{~d}$

inhibit cell proliferation and reduce the viability of A549 cells.

DNA Binding Properties Although there is some evidence to suggest that other biological targets, including RNA or proteins, may be important in cisplatin binding, it is generally accepted that DNA is the primary target. ${ }^{30)}$ Similarly, the interactions between small molecules and DNA are primarily responsible for antitumor activity. The DNA replication in tumor cells can be blocked via the intercalations of small molecules between two consecutive base pairs of DNA. ${ }^{31)}$ Generally, the active compounds possess an approximately planar structure as well as some hydrophobic characteristics to maximize intercalations. The DNA binding properties of the complex have been studied using several analytical methods, including the fluorescence spectroscopy, fluorescence polarization, DNA viscosity measurements as well as agarose gel electrophoresis.

Fluorescence Emission Titration The ability of the complex binding to ct-DNA was primarily investigated by fluorescence spectroscopy using ethidium bromide (EB) as a competitive DNA binding probe. EB is a classical fluorescent probe that binding to ct-DNA via an intercalation mode. ${ }^{32)}$

In the competitive binding experiments, the EB-ct-DNA solution $([\mathrm{EB}] /[\mathrm{DNA}]=1: 10)$ exhibited peak emission at $597 \mathrm{~nm}$ upon $350 \mathrm{~nm}$ UV light excitation, indicating that EB molecules intercalated between two adjacent base pairs of ctDNA and sufficiently protected from fluorescence quenching by polar solvent molecules. The emission spectra of EB-ctDNA system in the presence of complex are shown in Fig. 6. With the [complex]/[DNA]/[EB] ratios ranging from $1: 10: 1$ to $10: 10: 1$, the peak fluorescence intensity of EB gradually decreased from 210.5 to 141.6 , with a total quenching percentage of $32.7 \%$. The results indicate that there exist competitive DNA binding between complex and EB as a consequence of their similar intercalative binding modes to DNA. ${ }^{26,27)}$ Furthermore, the quenching constant, $K_{\mathrm{q}}$, for complex, was quantitatively evaluated based on the Stern-Volmer equation. ${ }^{21)}$ The $K_{\mathrm{q}}$ value for complex was found to be $5.49 \times 10^{3} \mathrm{~L} \cdot \mathrm{mol}^{-1}$, indicating a relatively weak intercalative binding ability of the complex compared to the classic intercalative agent EB.

Fluorescence Polarization Analysis Fluorescence polarization analysis is a valuable tool for studying the interactions between small molecules and DNA, by which the convincible information of binding mode can be inferred. ${ }^{15)}$ Small

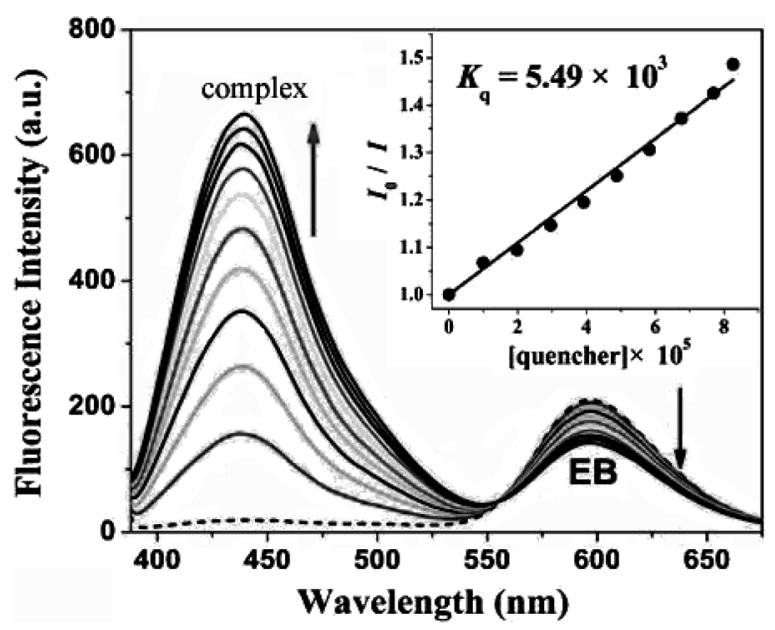

Fig. 6. Fluorescence Emission Spectra of EB Bound with ct-DNA $\left([\mathrm{DNA}]=2.0 \times 10^{-4} \mathrm{M},[\mathrm{EB}]=2.0 \times 10^{-5} \mathrm{M}\right)$ in the Absence (Dashed Line--.) and Presence (Solid Lines-) of Complex with [Complex]/[GelRed] Ratios Ranging from $1: 1$ to $10: 1$

Inset: linear fitting for quenching constant $K_{\mathrm{q}}$ based on Stern-Volmer equation.

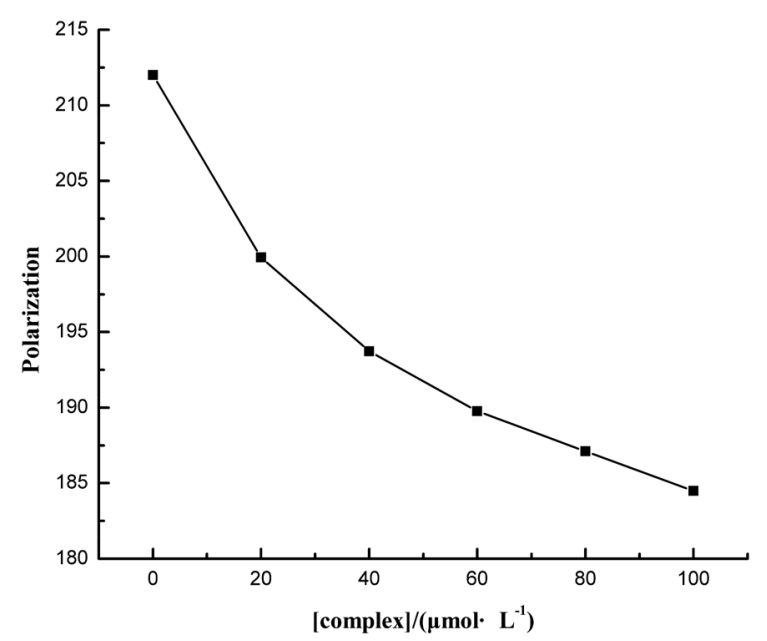

Fig. 7. Fluorescence Polarization Analysis of GelRed as Intercalative Binding Probe Bound with ct-DNA under the Addition of Complex with Increasing Concentrations

$[D N A]=7.0 \times 10^{-5} \mathrm{M},[$ GelRed $]=1.0 \times 10^{-5} \mathrm{M}$, the complex was added with increasing concentrations ranging from 2.0 to $10.0 \times 10^{-5} \mathrm{M}$.

molecules in aqueous solution exhibit a weak polarization in fluorescence emission due to their rapid rotational diffusion. However, the rotational diffusion would become restricted when the small molecules intercalate between two consecutive base pairs of DNA, and consequently, the fluorescence polarization degree would increase significantly. In contrast, other external interactions such as groove binding and electrostatic interaction, however, do not exhibit the similar effect, i.e., they do not cause an obvious change in the fluorescence polarization. ${ }^{33)}$ In this work, GelRed was chosen as the intercalative binding probe for fluorescence polarization analysis. As shown in Fig. 7, the polarization degree of GelRed bound to ct-DNA was measured to be 212 at a [DNA]/[GelRed] ratio of $7: 1$. After the addition of the complex into the GelRed/ct-DNA binary system, significant decreases on the polarization degree of GelRed were observed. As [complex]/[DNA]/[GelRed] ratio gradually increased from $2: 7: 1$ to $10: 7: 1$, the polarization degree of GelRed decreased by $13.0 \%$, i.e., from 212 to 184.5 . 
These results provide additional evidence for the existence of competitive intercalative binding to ct-DNA between GelRed and complex, in which the complex may partly displace the GelRed molecules intercalating between two consecutive base pairs of DNA and consequently some GelRed molecules would be forced back into the aqueous solution, leading to a decrease in its fluorescence polarization.

DNA Viscosity Measurements When small planar molecules intercalate into two adjacent base pairs of DNA, DNA double helix is relaxed to accommodate the intercalation, resulting in the lengthening of DNA helix. The viscosity of DNA solution is very sensitive to the length of DNA, and the increased viscosity of DNA solution is generally considered to be associated with an intercalative binding mode, while other interaction modes, such as groove binding and electrostatic attraction, will not induce obvious increase on viscosity of DNA solutions. ${ }^{34)}$

The changes on the viscosity of ct-DNA solution in the presence of the complex were shown in Fig. 8, in which EB was employed as the intercalative binding indicator for comparison. The addition of the complex resulted in an obvious increase in the viscosity of ct-DNA solution. As the [complex]/[DNA] ratios gradually increased from 0.01 to 0.09 , the viscosity of DNA solution increased by $12.3 \%$, which further confirmed the intercalative binding mode of the complex to ct-DNA. In contrast, EB induced a total $19.7 \%$ increase in the viscosity of DNA solution under the same condition. These results demonstrate that EB exhibits higher intercalative binding ability to DNA than the complex. ${ }^{35)}$ This is consistent with the results of the above spectroscopic analyses.

Electrophoretic Gel Shift Assay The interaction mode of the complex to pUC19 plasmid DNA was examined by agarose gel electrophoresis assay. pUC 19 DNA alone consists of three forms of DNA with different electrophoretic mobilities, including supercoiled DNA (Form I), open-circled DNA (Form II) and linear DNA (Form III) possessing the highest, the lowest and moderate mobility, respectively. As indicated in lane 1 of Fig. 9, pUC19 DNA alone showed predominant fraction of form I DNA. However, in the presence of complex at various concentrations of 20,40, 60, 80 and $100 \mu \mathrm{M}$, each plasmid DNA sample exhibited obvious variation in electrophoretic mobility, as indicated in lanes 2-6. Particularly, the supercoiled form DNA (Form I) exhibited an obvious lower electrophoretic mobility in the presence of the complex at lower concentrations of 20,40 and $60 \mu \mathrm{M}$. It was consistent with the results of pUC19 DNA in the presence of EB, further confirming that the complex bind intercalatively to DNA as EB does. ${ }^{36-37)}$ However, because the mobility of Form I DNA was reduced more significantly in the presence of $E B$, the intercalative binding strength of the complex to DNA may be relatively weaker compared to that of EB. At a higher the complex concentration of $80 \mu \mathrm{M}$, the form I DNA was converted to its open-circular form (the form II DNA), indicating the cleavage of a single DNA chain. Nevertheless, at a still higher complex concentration of $100 \mu \mathrm{M}$, no obvious DNA segments can be detected, which is probably due to the intensive DNA cleavage by the complex. These results indicated that the complex may possess the potent DNA cleavage ability at the concentrations higher than $80 \mu \mathrm{M}^{38)}$

In summary, the results of fluorescence emission titration indicated that the complex had a low quenching constant $K_{\mathrm{q}}$

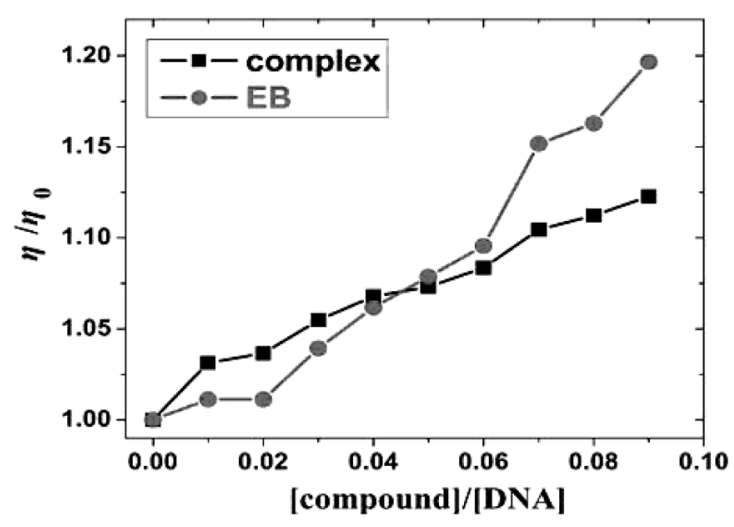

Fig. 8. Relative Viscosity Increments of ct-DNA Solution Bound with Complex with Increasing [Complex]/[DNA] Ratios in the 0.01 to 0.09 Range

EB as classic intercalative agent was set for comparison.

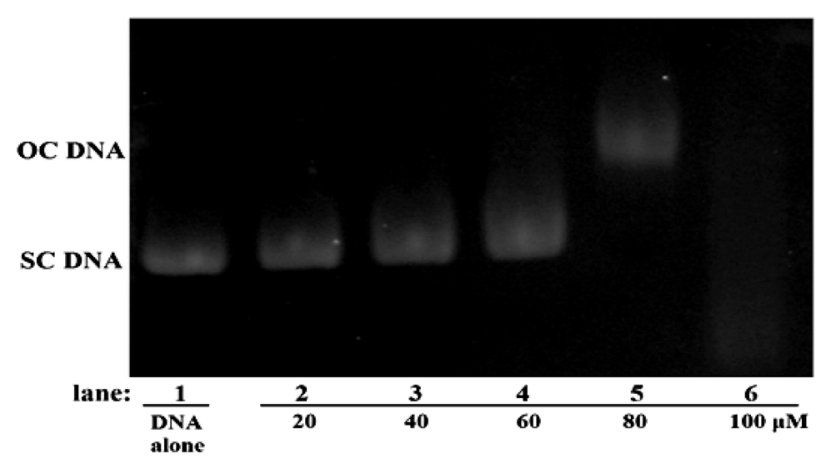

Fig. 9. Electrophoretic Mobility Shift Assay of Plasmid pUC19 DNA Treated with the Complex

$\left(5.49 \times 10^{3}\right)$, and could intercalate into DNA. The intercalative binding of complex to DNA had been further confirmed by the results of fluorescence polarization analysis, viscosity measurements and agarose gel electrophoresis assay.

\section{Concluding Remarks}

A mononuclear planar platinum(II) complex of Schiff base ligand that derived from $o$-phenylenediamine and 5-chlorosalicylaldehyde was synthesized and fully characterized. The complex exhibited potent in vitro cytotoxicities against six tested human tumor cell lines with $\mathrm{IC}_{50}$ values of $c a .11 .61 \mu \mathrm{M}$. The complex induced G1-phase arrest and apoptosis in A549 cells in a dose-dependent manner. The binding properties of the complex to DNA were investigated by several methods. The results demonstrate that the most probable binding mode of the complex was intercalation.

Supplementary Material Crystallographic data for the structural analysis have been deposited with the Cambridge Crystallographic Data Centre, CCDC No. 897133 for the complex. The data can be obtained free of charge via http://www. ccdc.cam.ac.uk, or from the Cambridge Crystallographic Data Centre, 12 Union Road, Cambridge CB21EZ, UK; fax: $(+44)$ 1223-336-033; or e-mail:deposit@ccdc.cam.ac.uk.

Acknowledgments This work was supported by Natural Science Foundation of China (No. 21271051), National Basic Research Program of China (No. 2012CB723501), IRT1225 
and Natural Science Foundation of Guangxi Province of China (Nos. 2012GXNSFDA053005, 2012GXNSFDA385001) as well as Bagui Scholar Program of Guangxi, China.

\section{References}

1) Jung Y., Lippard S. J., Chem. Rev., 107, 1387-1407 (2007).

2) Bruijinincx P. C. A., Sadler P. J., Curr. Opin. Chem. Biol., 12, 197-206 (2008).

3) Xu D., Min Y., Cheng Q, Shi H., Wei K., Arnesano F., Natile G., Liu Y., J. Inorg. Biochem., 129, 15-22 (2013).

4) Zhang J., Wang X., Tu C., Lin J., Ding J., Lin L., Wang Z., He C., Yan C., You X., Guo Z., J. Med. Chem., 46, 3502-3507 (2003).

5) Ruiz J., Lorenzo J., Vicente C., López G., López-de-Luzuriaga J. M., Monge M., Avilés F. X., Bautista D., Moreno V., Laguna A., Inorg. Chem., 47, 6990-7001 (2008).

6) Ren S., Wang R., Komatsu K., Bonaz-Krause P., Zyrianov Y., McKenna C. E., Csipke C., Tokes Z. A., Lien E. J., J. Med. Chem., 45, 410-419 (2002).

7) Piatak D. M., Yen C. C., Kennedy R. V. Jr., J. Med. Chem., 13, 769-770 (1970).

8) Rousso I., Friedman N., Sheves M., Ottolenghi M., Biochemistry, 34, 12059-12065 (1995).

9) Bassov T., Sheves M., Biochemistry, 25, 5249-5258 (1986).

10) Wu P., Ma D.-L., Leung C.-H., Yan S.-C., Zhu N., Abagyan R., Che C.-M., Chemistry, 15, 13008-13021 (2009).

11) Sylvain K. R., Bernier J.-L., Waring M. J., Colson P., Houssier C., Bailly C., J. Org. Chem., 61, 2326-2331 (1996).

12) Santanu B., Subhrangsu S. M., J. Chem. Soc., Chem. Commun., 24, 2489-2490 (1995).

13) Gravert D. J., Griffin J. H., J. Org. Chem., 58, 820-822 (1993).

14) El-Sherif A. A., Eldebss T. M. A., Spectrochimica Acta, Part A, 79, 1803-1814 (2011)

15) Sheldrick G. M., "SHELXTL-97, Program for Refinement of Crystal Structures," University of Göttingen, Germany, 1997.

16) Sheldrick G. M., "SHELXS-97, Program for Solution of Crystal Structures," University of Göttingen, Germany, 1997.

17) Alley M. C., Scudiero D. A., Monks A., Hursey M. L., Czerwinski M. J., Fine D. L., Abbott B. J., Mayo J. G., Shoemaker R. H., Boyd M. R., Cancer Res., 48, 589-601 (1988).

18) Hancock C. N., Macias A., Lee E. K., Yu S. Y., MacKerell A. D. Jr., Shapiro P., J. Med. Chem., 48, 4586-4595 (2005).

19) Lin J.-C., Yang S.-C., Hong T.-M., Yu S.-L., Shi Q., Wei L., Chen
H.-Y., Yang P.-C., Lee K.-H., J. Med. Chem., 52, 1903-1911 (2009).

20) Kumar C. V., Barton J. K., Turro N. J., J. Am. Chem. Soc., 107, 5518-5523 (1985).

21) Ghosh S., Barve A. C., Kumbhar A. A., Kumbhar A. S., Puranik V. G., Datar P. A., Sonawane U. B., Joshi R. R., J. Inorg. Biochem., 100, 331-343 (2006).

22) Reichmann M. F., Rice S. A., Thomas C. A., Doty P., J. Am. Chem. Soc., 76, 3047-3053 (1954).

23) Csapo Z., Gerstner A., Sasvari-Szekely M., Guttman A., Anal. Chem., 72, 2519-2525 (2000).

24) Özalp-Yaman Ş., de Hoog P., Amadei G., Pitié M., Gamez P., Dewelle J., Mijatovic T., Meunier B., Kiss R., Reedijk J., Chemistry, 14, 3418-3426 (2008).

25) Dunham S. U., Chifotides H. T., Mikulski S., Burr A. E., Dunbar K. R., Biochemistry, 44, 996-1003 (2005).

26) Zhang G., Guo J., Zhao N., Wang J., Sens. Actuators B Chem., 144, 239-246 (2010)

27) Otero L., Vieites M., Boiani L., Denicola A., Rigol C., Opazo L. Olea-Azar C., Maya J. D., Morello A., Krauth-Siegel R. L., Piro O. E., Castellano E., González M., Gambino D., Cerecetto H., J. Med. Chem., 49, 3322-3331 (2006).

28) Ihmels H., Otto D., Top. Curr. Chem., 258, 161-204 (2005).

29) Jordan P., Carmo-Fonseca M., Cell. Mol. Life Sci., 57, 1229-1235 (2000).

30) Najajreh Y., Prilutski D., Ardeli-Tzaraf Y., Perez J. M., Khazanov E., Barenholz Y., Kasparkova J., Brabec V., Gibson D., Angew. Chem. Int. Ed., 44, 2885-2887 (2005).

31) Galindo M. A., Olea D., Romero M. A., Gòmez J., del Castillo P., Hannon M. J., Rodger A., Zamora F., Navarro J. A., Chemistry, 13, 5075-5081 (2007).

32) Olmsted III J., Kearns D. R., Biochemistry, 16, 3647-3654 (1977).

33) Kumar C. V., Asuncion E. H., J. Am. Chem. Soc., 115, 8547-8553 (1993).

34) Rajput C., Rutkaite R., Swanson L., Haq I., Thomas J. A., Chemistry, 12, 4611-4619 (2006).

35) Chen Z.-F., Shi Y.-F., Liu Y.-C., Hong X., Geng B., Peng Y., Liang H., Inorg. Chem., 51, 1998-2009 (2012).

36) Chen Z.-F., Liu Y.-C., Peng Y., Hong X., Wang H.-H., Zhang M.-M., Liang H., J. Biol. Inorg. Chem., 17, 247-261 (2012).

37) Baraldi P. G., Bovero A., Fruttarolo F., Preti D., Tabrizi M. A., Pavani M. G., Romagnoli R., Med. Res. Rev., 24, 475-528 (2004).

38) Vaidyanathan V. G., Nair B. U., Dalton Trans., 17, 2842-2848 (2005). 